\title{
Memories and history of Hansen's disease in Brazil told by witnesses (1960-2000)
}

\section{Memória e história da hanseníase no Brasil através de depoentes (1960-2000)}

\author{
Laurinda Rosa Maciel \\ Researcher, Casa de Oswaldo Cruz/Fundação Oswaldo Cruz \\ Av. Brasil 4365, Prédio do Relógio \\ 21045-900 Rio de Janeiro - RJ Brasil \\ laurinda@coc.fiocruz.br \\ Maria Leide Wand-del-Rey de Oliveira \\ Professor, Faculty of Medicine, Universidade Federal do Rio de Janeiro \\ Ladeira Tabajaras, 126/1008 \\ 22031-110 Rio de Janeiro - RJ Brasil \\ mleide@uol.com.br or mleide@hcff.ufrj.br \\ Maria Eugênia N. Gallo \\ Researcher and director, Fiocruz Leprosy Laboratory \\ Mariana Santos Damasco \\ Intern, Fiocruz Scientific Initiation Program
}

ROSA MACIEL, L.; OLIVEIRA, M. L. W.-del-R. de; GALLO, M. E. N. and Damasco, M. S.: 'Memories and history of Hansen's disease in Brazil told by witnesses (1960-2000'. História, Ciências, Saúde — Manguinbos. Vol. 10 (supplement 1.): 308--36, 2003.

This report is a preliminary result of a survey on memories and history of Hansen's disease, or 'hanseniasis', prepared by the Fundação Oswaldo Cruz (Fiocruz) and the Universidade Federal do Rio de Janeiro (UFRJ) using statements from those who have been afflicted by the disease or those that have fought against it. It outlines the methodology used by the authors and gives a succinct history of Hansen's disease in Brazil, together with information on the stage of the survey with extracts from our archives of statements. The founding and the role of Movement for the Reintegration of People Afflicted by Hansen's Disease (Morhan) are explained in the testimony of Thomas Frist, a social scientist who worked in Brazil in the 1970s and 1980s, when the country's old colonies were being restructured, and Cristiano Torres, a former patient who spent time in prevention centers and leproseries in Pará state and who is now active in proposing new policy for the control of Hansen's disease.

KEYWORDS: oral history, compulsory isolation, Abrahão Rotberg, leprosy, Hansen's disease, Morhan, resocialization, prevention center.

ROSA MACIEL, L.; OLIVEIRA, M. L. W. -del-R. de; GALLO, M. E. N.; Damasco, M. S.: 'Memória e história da hanseníase no Brasil através de depoentes (1960-2000)'. História, Ciências, Saúde - Manguinbos. Vol. 10 (suplemento 1), 308-36, 2003.

Este trabalbo é um resultado preliminar de pesquisa sobre memória e história da hanseniase, desenvolvida pela Fundação Oswaldo Cruz (Fiocruz) e Universidade Federal do Rio de Janeiro (UFRJ), através de depoimentos de quem padeceu da doença ou atuou contra ela. Apresenta as opções metodológicas adotadas pelos autores, um sucinto bistórico da hanseníase no Brasil e dados a respeito do estágio em que se encont ra a pesquisa, com extratos de depoimentos que constituem o acervo gerado. Na década de 1980 bouve avanços, como a adoção do tratamento através da poliquimioterapia, que provocou a redução do indice de prevalência da doença, que passou de 16,3 casos por dez mil habitantes em 1985, para 4,57 casos para dez mil habitantes em 2000, em nosso país. A gênese e as atividades do Movimento de Reintegração das Pessoas Atingidas pela Hanseníase (Morhan) são reveladas pelos testemunhos de Thomas Frist, cientista social norte-americano que trabalbou no Brasil nas décadas de 1970 e 1980, periodo de reestruturação das antigas colônias, e pelode Cristiano Torres, ex-paciente, com passagens por preventórios e leprosários no Pará, personagem atuante, inclusive na proposição de políticas de controle da hanseníase. PALAVRAS-CHAVE: história oral, isolamento compulsório, Abrabão Rotberg, lepra, hanseníase, Morhan, ressocialização, preventório. 


\section{Introduction}

$\mathrm{T}$ he Memories and History of Hansen's Disease in Brazil Told by Witnesses (1960-2000) project is being developed in partnership with the UFRJ University Faculty of Medicine and two technical and scientific units of the Fundação Oswaldo Cruz, the Instituto Oswaldo Cruz and the Casa de Oswaldo Cruz. The main goal of the project is to create, with the help of oral history, an archive of statements from people involved in the various policies to combat Hansen's disease from 1960 to 2000.

Interviews are being held with members of the health profession who work or who have worked with patients in leproseries and clinics, or who worked on the board of disease control programs for research organizations and institutes. We also interviewed former patients, recently cured thanks to polychemotherapy or long discharged from leproseries, who have experienced the resocialization process. When conducing the interviews, we sought to combine key aspects of the official control policies, considered by some to be the 'official history', with the social representation of the disease in different categories and social groups.

The time period covered by the survey is characterized by significant changes: on the one hand, a widespread use of chemotherapy since the introduction of sulfone drugs at the end of the 1940s; on the other hand, nationwide public control policies recommending an end to compulsory isolation. During this period, there was a consolidation of the decentralization that began during government of Juscelino Kubitschek, in the 1950s.

The first accounts of cases of the disease in Brazil date back to the colonial period, leading us to believe that the bacillus was introduced to the Americas by European colonizers. ${ }^{1}$

These accounts were noted, analyzed and, very often, transcribed by Souza-Araújo (1956), who is still today acknowledged as the author of one of most comprehensive studies of the illness. The study presents details of the health reform implemented by Oswaldo Cruz in 1904, when a policy of compulsory notification was introduced. Oswaldo Cruz endorsed the isolation of patients on Ilha Grande, Rio de Janeiro State. In the first two decades, a policy of setting up leproseries in each state prevailed, before the shift to a nationwide compulsory segregation.

The Carlos Chagas reform, in 1920, gave rise to the National Public Health Department, within which the Leprosy and Venereal Disease Prophylaxis Inspectorate was created and regulated by decree $\mathrm{n}^{\circ} \mathbf{1 4 3 5 4}$,

\footnotetext{
${ }^{1}$ In a thesis presented for a 'livre-docência' (degree after the Doctorate) in Hygienics, Belmiro Valverde affirms the inexistence of leprosy among the indigenous. See Valverde (1915) and Dyer (1929).
} 
of $9 / 15 / 1921 .^{2}$ Articles 136 and 386 of the decree recommended the construction of leproseries, hospitals and dispensaries with funds allocated specifically for these ends. Nosocomial isolation occurred in establishments set up by federal, state and municipal governments, or by private associations.

The law was considered flexible because it permitted isolation at home and compulsory segregation was already in place in São Paulo State, regulated by the Health Code established by Emilio Ribas in 1917. The Inspectorate delegated complete responsibility for implementing these rules to state governments without checking that they were observed, nor did it effectively monitor the actions of state governments.

Between 1933 and 1935, the leprologist Ernani Agrícola, who worked for the Inspectorate that was later to close down, established the National Plan to Combat Leprosy during the government of Getúlio Vargas, adopting the centralized campanbista method already used to combat several diseases. The method was underpinned by leproseries, prevention centers and dispensaries, with the majority of investments allocated to the first two: the leprosery, which ensured segregation through the compulsory isolation of all known cases, and the prevention center, which treated the children of sick parents. Treatment at prevention centers was provided with the assistance of leading charities, notably the Federation of Aid Associations for Lepers and Defense against Leprosy, founded in 1926 by Alice de Toledo with the support of women from São Paulo's high society and later from other states in the country. ${ }^{3}$

In 1941, the Public Health and Education Minister Gustavo Capanema proposed an alteration to the organizational structure of his ministry. He set up the National Services, further centralizing the control over health organizations. The control of the National Service for Leprosy was handed to Ernani Agrícola. ${ }^{4}$

Segregation began to be criticized, a policy that other endemic countries would abolish at the end of the 1940s without jeopardizing the control of the endemic, which benefited enormously from the discovery of sulfone drugs, the first form of chemotherapy effective

\footnotetext{
2 This decree replaced $\mathrm{n}$ o 3987, de 1/2/1920, which reorganized the Public Health Services, creating the Leprosy and Venereal Disease Prophylaxis Services. The National Public Health Department regulations were approved on May 26, 1920, by Decree $\mathrm{n}^{\mathrm{o}} 14189$. It was harshly criticized by the medical community in their journals, leading the government to approve another set of regulations (Decree $\mathrm{n}^{\mathrm{o}}$ 14354, on 9.15.1920). The transcript of the articles referring to leprosy in the aforementioned decrees may be found in part III of the book by Souza-Araújo (1956).

3 The Rio de Janeiro office of this federation was created in 1928. Its vice president was Laurinda Santos Lobo, a Rio society woman. It was presided by Eunice Weaver from 1930 to 1970 .

${ }^{4}$ Although the service was created in 1941, its regulations were only approved in 1955 , by Decree $\mathrm{n}^{\mathrm{0}} 36771$, of $1 / 12$. For more information on this reform, see Hochman and Fonseca (2000, p. 173-93 and Hochman, (2001, pp. 127-51).
} 
against the bacillus that causes the disease. ${ }^{5}$ The dispensary now became the most valuable of the three centers, gaining more importance after 1956, when a new disease control policy was introduced. This policy was consolidated in 1959 with the so-called National Campaign Against Leprosy, which observed the decisions taken at the VII International Leprosy Congress the previous year in Tokyo. Although it had already been supposedly banned, compulsory isolation was only formally abandoned by law no 986 , of 7 May 1962. The National Campaign Against Leprosy was dissolved, increasing the amount of outpatient treatment in national health clinics run by state health departments. ${ }^{6}$

In the 1970s, a movement led by the Brazilian Dermatology and Leprosy Society (Rotberg, 1970) called for the replacement of the term leprosy with Hansen's disease, which was formalized in decree $\mathrm{n}^{\circ} \mathbf{1 6 5}$, of 14 May 1976 by the National Sanitary Dermatology Division. ${ }^{7}$

As a result of the decentralized treatment of the disease, patients began to be treated under the responsibility of state health departments and, more recently, by municipal departments. Enacted into law in 1966, the decentralization only began to be properly implemented from the decisions of the VIII National Health Conference in 1986 and only gained the necessary bureaucratic instruments to be applied on a municipal scale with the NOB/97 and NOAS2001, the Basic Operational Rule of the SUS National Health System and the Health Assistance Operational Rule, respectively.

In the 1980s, three important events occurred in the history of Hansen's disease. The adoption of polychemotherapy by the World Health Organization drastically cut the treatment time of the disease and permitted a reorganization of regional and local services for treating patients. A public campaign in the national media helped spread the use of the term Hansen's disease and differentiated its characteristics from the old conceptions associated with 'leprosy'. Finally, the 1980s witnessed the emergence of the Movement for the Reintegration of Hansen's Disease Patients (MORHAN). This organization was initially created to ensure the rights of patients from leper colonies due to their isolation, and it is today one of the most successful Brazilian social movements, with representation in the National Health Council.

\footnotetext{
5 "When we hospitalize an advanced case we lose another struggle. ... for every patient who joins a leprosery, there are four, five or six others that do not need to ..." - - said Rabello (in Diniz, May 1948). In 1948, the Brazilian Leprology Association (ABL), the first Brazilian scientific society, was inaugurated. These days, it is called the Brazilian Hansen's Disease Association (ABH).

${ }^{6}$ For more details, see Del Fávero (1971).

${ }^{7}$ The strategy of classifying the disease with existing skin diseases to reduce the stigma is still in place today in some metropolitan regions, particularly in the South and Southeast, raising controversies in the public health system due to the delegation of these patients to dermatologists. Oliveira (1990) cites conflicts between the methods of the scientific societies that represent dermatologists and those of the public health area.
} 
The prevalence of the disease has diminished from 16.3 cases per ten thousand in 1985 to 4.57 per ten thousand in 2000. There has also been a sizable reduction in deformities caused by the disease as a result of the relatively early diagnosis and the efficiency of the treatment. However, there has been almost no change in the number of new cases of Hansen's disease and Brazil is still responsible for nearly $80 \%$ of the diagnosed cases on the American continent. A target has recently been set to eliminate the disease from the country by 2005 , which means actually achieving much lower rates: one case per ten thousand inhabitants. While this rate has already been achieved in Brazil's southern states of Rio Grande do Sul and Santa Catarina, it is unlikely that it will be accomplished in any of the tropical states in the Amazon region by the set date.

Decentralization has been championed by the National Council of State and Municipal Health Departments (Conasems) and municipal Hansen's disease elimination programs have been strengthened, although somewhat unevenly and far less then necessary in some of the more endemic regions of the country.

\section{Methodological issues}

The methodology of oral history consists of a series of techniques used to gather, prepare and use recorded interviews as primary sources for researchers from various fields. The interviews are conducted using previously arranged scripts based on the witness' curriculum vitae. The scripts are used only as guidelines and all interviewees are encouraged during their statements to follow their memories and to reconstruct their history and any related facts that could be absent from other forms of documented sources.

Interviews are recorded on magnetic tapes, transcribed and then edited. This provides us with two separate documents: one 'recorded' and another 'written', which complement each other as the latter loses qualities such as voice intonation, common errors of oral communication and hesitations that are only detectable on the tapes. We emphasize the significance the silence, forgetfulness and hesitation may lend to the meaning of the statement, as these signs are often the best way we can understand what has not been explicitly spoken. The final stages of the interview process are to check the accuracy of the transcript and prepare summaries and short biographies, to facilitate the research in the future.

The methodology of oral history allows us to register the ideas, emotions and experiences of the witnesses, creating an important source for research on the history of Hansen's disease in Brazil. By using the oral method, we can probe into the memories of a community, supplied by its doctors, patients, former patients or residents of a determined place. The oral narrative will always be a form of reinvigorating the conscience of individuals as narrators of history, as it opposes the 
current tendency of disregarding the spoken word as a transmitter of life experiences in societies that are increasingly more dominated by technological and industrial advances, that interfere in practically all aspects of our lives.

It is a multidisciplinary technique that has been successfully applied in several social sciences, particularly History and Anthropology. In the mid-1950s, researchers such as Maria Isaura Pereira de Queiroz and Roger Bastide used the oral technique to come up with a research methodology to overcome the difficulties of working with peasants, rural laborers and other social groups that rarely leave behind any written records of their existence. Oral history has therefore become an important tool for both Brazilian and foreign researchers who study the underprivileged. By the 1960s and 1970s, it started to be used frequently by historians: not only does it compensate for possible gaps in written documentation, but it also clarifies certain aspects of the history of individuals and groups that are only available through speaking. ${ }^{8}$

Since the 1980s, the method has been used by research institutes to accumulate archives to preserve the memory of an institution, a social group or a disease, such as with our case, to complement the existing records preserved in written or iconographic documents. Suitable for analysis and criticism in the same way as text or image documents, oral narratives are simply sources of an alterative origin, but just as important as the others. ${ }^{9}$

\section{Results}

The interviews that have already been conducted or those that are still underway have provided important new information on the history of Hansen's disease in Brazil, particularly on the final stages of compulsory isolation and the resocialization of discharged patients from leper colony hospitals. The accounts of doctors and former patients have shed a new light on these stages of the history of the disease and they also illustrated the role of these people in the history.

Our choice of interview style was life history rather than thematic, although we were constantly focusing on themes related with Hansen's disease. The interviews frequently presented us with facts or interpretations not included in traditional works of history. They reveal that the efforts of the past fifty years to suppress compulsory isolation and to resocialize patients have not been sufficient to forestall the consequences of the harsh policy implemented in the period beforehand. The transformation of colony hospitals has been a slow process and in

\footnotetext{
${ }^{8}$ For more on the methodology of oral history, see Ferreira, Fernandes \& Alberti (2000); Ferreira, \& Amado (1996); Ferreira (1994); Burke (1992).

${ }^{9}$ See reports submitted to the $\mathrm{X}^{\text {th }}$ International Oral History Conference, whose focus was "Oral History: Challenges for the XXIst Century." Rio de Janeiro, June 14-18, 1998.
} 
certain areas of the country, they still play an important role for Hansen's disease patients both new and old.

The memories of the social players involved in this process, many now retired, alone and forgotten, enable us to understand the errors of public policy and the disputes engraved in the heart of the scientific community. It is remarkable that there are still so many former patients available to interview that still live in the old leproseries, or nearby, some fifty years after the inefficiency of compulsory isolation was acknowledged.

In the following table, we have listed the professional qualifications of the witnesses beside their names, along with the length of each interview, the years they were involved with Hansen's disease and the control policies in effect at that time. In the case of former patients, the table illustrates the amount of time and the years they were interned and other biographical information.

Table of witnesses and their relation with public control policies

Health sector Professionals

Interviewee/length of interview Years involved Professional qualifications of interviewee
and control policy in place at the time

Abrahão Rotberg, doctor and professor in São Paulo, nearly four hours long
From the 1930s to the 1970 s

Now retired, he worked during the main years of the compulsory isolation policy as a doctor for the Leprosy Prophylaxis Department in São Paulo. He witnessed the start of the process to resocialize patients and the shifting of leper colony hospital management to state governments. He was active in the Hansen's Disease Control Program, by the Institute of Health, in São Paulo, and participated in the advisory committee of the Brazilian Hansen's Disease Association. He is responsible for the introduction of the neologism "hanseníase" in the Brazilian Public Health.

Antônio A. Baraúna Bezerra, health officer in the state of Acre, nearly an hour long

The 1960s to the present day

He was a community officer for the National Leprosy Campaign in Acre, experienced the transfer of leper colony hospitals the state and municipal governments. Today, he is a health officer in Cruzeiro do Sul, Acre.

He worked in the Aymorés Sanatorium in Bauro, São

Diltor V. Araújo Opromolla, doctor and researcher in São Paulo, the present day nearly three hours long
From the 1950s to Paulo State, during the period of compulsory isolation and he witnessed the process of transforming that in a Dermatologic Institute called Lauro de Souza Lima, one of the most important reference center on Hansen's disease in Brazil. He was a member of the advisory committee for the Brazilian Hansen's Disease Association and is now a member of the International Leprosy Association (ILA).
Germano Traple, $\quad$ From 1972 to doctor from the state of Paraná who 1990 worked in the state health department, nearly an hour long
Now retired, he was involved in the final stages of the compulsory isolation control policy. Experienced the process of transferring management of colony hospitals in Paraná to state and municipal governments. 
Table of witnesses and their relation with public control policies

\begin{tabular}{ll}
\hline Interviewee/length of interview Years involved & $\begin{array}{l}\text { Professional qualifications of interviewee } \\
\text { and control policy in place at the time }\end{array}$ \\
\hline
\end{tabular}

Luís Aurélio Alves Orsini, doctor in state of Minas Gerais, nearly an hour long

From the 1940 s to the 1990 s
Now retired, he worked during the stages of compulsory isolation, resocialization of patients and the transfer of Minas Gerais State leper colony hospital management to the state government. He also participated in the Program to Control Hansen's Disease in the state.

\author{
Luís Marino Bechelli, \\ Doctor and professor in São Paulo, \\ worked for PAHO and WHO, \\ nearly two hours long
}

From the 1940s to the $1990 \mathrm{~s}$

Now retired, he worked during the implementation of compulsory isolation by the Leprosy Prophylaxis Department in São Paulo. He was in charge of regional and global. Hansen's disease control programs by the PAHO and WHO. He was a member of the International Leprosy Association (ILO).
From the 1950s to the 1980s
Now retired, she worked in the Leprology Institute in
São Cristóvão, Rio de Janeiro State, linked to the
Lygia Madeira César de

Andrade, doctor from Rio de Janeiro, nearly three hours long Leprosy Prophylaxis Department, Ministry of Health. In the 1970s, she ran this institute after management was transferred to Fiocruz and it was renamed Hansen's Disease Laboratory.

Now retired, he was involved during the stage of compulsory isolation in the states of Pará and Ceará. In Rio de Janeiro, he worked for the Leprology Institute, part of the Leprosy Prophylaxis Department and the National Campaign to Combat Leprosy.

Osmar Mattos, doctor in states of From the 1940 nearly three hours long to the 1970 s
From the 1960s to the present day professor in Rio de Janeiro, nearly five hours long

Rubem David Azulay, doctor and professor of dermatology in Rio de Janeiro, nearly three hours long
From the 1940s to He worked in the Leprosy Prophylaxis Department, the present day from the Federal Delegateship of Rio de Janeiro. He is a member of the Brazilian Hansen's Disease Association and is dedicated to teaching and researching Hansen's disease.
Silvia Viscellio, Italian professor and nun in Campo Grande, Mato Grosso do Sul State, nearly thirty minutes long
He worked for the Leprology Institute and is a member of the Brazilian Hansen's Disease Association and is dedicated to teaching and researching Hansen's disease.
From the 1960s to She worked in prevention centers in Mato Grosso do the present day Sul during the stage of compulsory isolation. She participated in the process to resocialize patients and now works in the São Julião Hospital, a leading SUS national health system hospital. 
Table of witnesses and their relation with public control policies

\begin{tabular}{lll}
\hline Interviewee/length of interview & Years involved & $\begin{array}{l}\text { Professional qualifications of interviewee } \\
\text { and control policy in place at the time }\end{array}$ \\
\hline $\begin{array}{l}\text { Thomas Ferran Frist, North } \\
\text { American sociologist in Bauru, São }\end{array}$ & $\begin{array}{l}\text { From the 1970s to } \\
\text { the 1990s }\end{array}$ & $\begin{array}{l}\text { He participated in the process to improve the Lauro } \\
\text { de Souza Lima Institute and transform it into a } \\
\text { specialist center. He set up Sorri (Society for the } \\
\text { Rehabilitation and Reintegration of the Disabled) and } \\
\text { Morhan (Movement for the Reintegration of People } \\
\text { Afflicted by Hansen's Disease), both organizations for } \\
\text { resocializing patients who have been treated for } \\
\text { Hansen's disease, in partnership with international } \\
\text { NGOs. }\end{array}$ \\
\hline $\begin{array}{l}\text { William John Woods, doctor, } \\
\text { coordinator of Plan to Eliminate } \\
\text { Hansen's Disease in Acre, nearly } \\
\text { one hour long }\end{array}$ & $\begin{array}{l}\text { From the 1970s to } \\
\text { the present day }\end{array}$ & $\begin{array}{l}\text { He worked with the Acre State Health Department } \\
\text { during the stage when the management of leper } \\
\text { colony hospitals was being transferred to state and } \\
\text { municipal governments. He works in partnership with } \\
\text { international NGOs. }\end{array}$ \\
\hline
\end{tabular}

Table of witnesses and their relation with public control policies I - FORMER PATIENTS

\begin{tabular}{|c|c|c|}
\hline $\begin{array}{l}\text { Name of interviewee/length } \\
\text { of interview }\end{array}$ & Years hospitalized & Control policy \\
\hline $\begin{array}{l}\text { Antônio de Oliveira Borges } \\
\text { Júnior, nearly an hour long }\end{array}$ & $\begin{array}{l}\text { Hospitalized in 1943; } \\
\text { discharged in } 1953\end{array}$ & $\begin{array}{l}\text { He now works for Morhan, in the state of } \\
\text { Bahia. He was interned during the stage of } \\
\text { compulsory isolation at the José Menezes } \\
\text { Colony Hospital, Bahia State. He participated } \\
\text { in the process to resocialize patients and in } \\
\text { the stage of transferring management of leper } \\
\text { colony hospitals to state and municipal } \\
\text { governments. }\end{array}$ \\
\hline $\begin{array}{l}\text { Cristiano Cláudio } \\
\text { Torres, nearly two hours long }\end{array}$ & $\begin{array}{l}\text { Prevention center in Belém, } \\
\text { transferred to Prata and } \\
\text { Marituba Leper Colonies, } \\
\text { Pará State }\end{array}$ & $\begin{array}{l}\text { Regional Morhan representative in Pará. He } \\
\text { was interned in prevention centers at the } \\
\text { time when compulsory isolation was policy, } \\
\text { experienced the resocialization process for } \\
\text { patients and witnessed the creation of } \\
\text { Morhan. }\end{array}$ \\
\hline $\begin{array}{l}\text { Fuad Abílio Abdala, lawyer } \\
\text { and member of MORHAN in } \\
\text { São Paulo, nearly two hours long }\end{array}$ & $\begin{array}{l}\text { Interned in 1935; discharged } \\
\text { in } 1948\end{array}$ & $\begin{array}{l}\text { Now retired, he was interned during the } \\
\text { period of compulsory isolation in Minas } \\
\text { Gerais State and in the Padre Bento } \\
\text { Sanatorium, in Guarulhos, São Paulo State. } \\
\text { He was active in the process to transfer } \\
\text { management of hospitals to state } \\
\text { governments and in the creation of Morhan, } \\
\text { having graduated in law from the University } \\
\text { of São Paulo. }\end{array}$ \\
\hline $\begin{array}{l}\text { Ulrico Frederico da Gama, } \\
\text { Rio de Janeiro and São Paulo, } \\
\text { nearly an hour long }\end{array}$ & $\begin{array}{l}\text { Interned from } 1946 \text { to } 1949 \\
\text { in the Tavares de Macedo } \\
\text { Hospital, Rio de Janeiro } \\
\text { State; from } 1949 \text { to } 1952 \text { in } \\
\text { Frei Antônio, Rio de Janeiro; } \\
\text { and from } 1952 \text { to } 1960 \text { in } \\
\text { the Padre Bento Sanatorium, } \\
\text { São Paulo }\end{array}$ & $\begin{array}{l}\text { Now a small businessman. He was interned } \\
\text { during the stage of compulsory isolation. He } \\
\text { participated in the process to resocialize } \\
\text { patients and in the transfer of leper colony } \\
\text { hospital management to state and municipal } \\
\text { governments. }\end{array}$ \\
\hline
\end{tabular}




\section{The testimonies}

As an illustration, we have transcribed passages from two testimonies taken by M. Leide W. de Oliveira and Laurinda Rosa Maciel, in the state of São Paulo, in May 2002.

Dr. Fuad Abílio Abdala is a former Hansen's disease patient and has sever skin lesions. He has a law degree from the University of São Paulo. He was interned when he was 16, at the end of the 1930s when São Paulo and Minas Gerais were two of the few states that applied a strict policy of compulsory isolation, so strict, in fact, that informing was encouraged. He was born in Uberada, Minas Gerais, in 1918 from Lebanese parents who emigrated to Brazil during World War I and settled in Pedregulho, on the border of São Paulo State with Minas Gerais. None of his three brothers or immediate family had Hansen's disease. We have extracted from his testimony a passage in which he describes how he discovered he had the disease:

I was at High School at the time and my father was a wealthy man... we had everything, imported bicycles, roller-skates. I was a happy child, very happy. And very studious ... I had gone to the gymnasium to check my exam results and an Aeronautics test I'd done. I'd passed both of them. I was contentedly on my way home to tell my family when a man told me to stop my bicycle in front of a house that had been converted into a health center, or something like it. I leaned my bicycle against the curb and said: "Yes, what do you want?" "Come here a minute." I remember thinking it odd because he was wearing gloves... I was 15 or 16 years old. I went into the waiting room and the man said: "You're a leper so you wont be leaving here again, your medicine will be here this afternoon."

So I said "let me tell my family." But they said "No!" And there was a policeman at the door, with a rifle. I couldn't even warn my family. I'd been informed on.

Then I saw a boy I knew in the street. I called out: "Take my bike and get my mother." My father was in Ribeirão Preto. A little later, they put me inside a truck and took me to a carriage on the railway line ... they were grabbing everybody. Afterwards I asked the doctor: "Why are you sending me to hospital? I haven't got anything." He said: "You'll contaminate the whole city!" I was a happy boy, a boy scout ... (laughter) It was 1935. I traveled all night to Cocais. I stayed there ten years presenting any symptoms at all. ${ }^{10}$

This statement illustrates the consequences for people's lives of such an authoritative health policy that did not even allow dubious

\footnotetext{
${ }^{10}$ Interview with Fuad Abílio Abdala, tape 1, side A, Project Memories and History of Hansen's disease in Brazil told by witnesses (1960-2000), May 2002, COC/Fiocruz Archives.
} 
diagnoses to be questioned. Fuad Abdala may have contracted Hansen's disease while he was interned at Cocais, in São Paulo State, which at the time was one of the country's most inhumane leproseries and very different from the Padre Bento Hospital in Guarulhos, also in São Paulo, which has been highly praised by former patients. ${ }^{11}$

Let us take a different case. Dr. Abrahão Rotberg, a practitioner and professor of dermatology, has been in contact with leprosy since the start of his career. As early as in his $6^{\text {th }}$ year at the São Paulo Faculty of Medicine, today a part of the University of São Paulo (USP), he did his training in the Padre Bento Hospital with Luís Marino Bechelli and other colleagues from his course. In 1935, they defended their doctorate theses on the disease. Abrahão Rotberg's thesis was on the Mitsuda Reaction, as a result of which he enjoyed tremendous professional prestige due to the new knowledge he spread on the relation between genetics and resistance to disease, a relation known as the Rotberg $\mathrm{N}$. Factor. ${ }^{12}$ In 1940, he was Leprosy Inspector in Greater São Paulo, precisely at the time of the oppressive application of compulsory isolation by the Leprosy Prophylaxis Department in the state. The following is a passage from his interview, in which he addresses very emotionally one of the most difficult moments of his career as a doctor.

The Leprosy Prophylaxis Department in São Paulo was rich and powerful. The boss was Francisco Salles Gomes Júnior, a surgeon who was like a health police officer. He was ruthless. The rule was total isolation for all informed cases, without consideration for the stage of the disease. ... Yes, I remember the case of one 12-yearold child, ... her mother crying and begging, begging... it was a tubercular nodule. I knew! I knew it wasn't contagious, but I had to obey orders! $!^{13}$ (crying).

In the 1950s, Rotberg worked in the Hansen's Disease Laboratory in the São Paulo neighborhood of Lapa and he was professor of the Paulista School of Medicine until 1975. In 1967, he headed up the

\footnotetext{
${ }^{11}$ In their statements, Fuad Abílio and Ulrico Frederico Gama refer to the positive characteristics of the Padre Bento Hospital, such as the cleanliness of the facilities, the competence of Dr. Lauro de Souza Lima and the beauty of the grounds. The leper colony hospitals built in Brazil were based on the United States model established in Carville and included individual houses for couples and community leisure areas, such as a cinema, a club, casino, church, etc. that were separate from the medical area.

12 Abrahão Rotberg was a pioneer in the spectral definition of Hansen's disease, discovering the existence of specific and natural immunity to Micobacterium leprae (Factor N) in most people; the possibility of the individual developing severe and contagious forms was related, therefore, to a defect in the immunity of a small minority of the population. See Rotberg (1937).

13 Interview with, tape 2, side B, Project Memories and History of Hansen's disease in Brazil told by witnesses (1960-2000), May 2002, COC/Fiocruz Archives.
} 
Leprosy Prophylaxis Department in the state. He was also active in the campaign to adopt the name Hansen's disease, "a new terminology free of derogatory terms such as 'leprosy', 'leper', 'leprosery', 'leper colony' and others" (MORHAN, 1985, p. 4).

The aforementioned examples illustrate the importance of oral history to document personal experiences with the disease and what it was like to have Hansen's disease or to be a doctor treating the illness during the policy of compulsory isolation. A conflict can be observed between the medical practice and the observance of technical authoritative rules that were often scientifically incorrect. ${ }^{14}$

This survey and the interviews conducted by its team will provide new and relevant information for those interested in the history of Hansen's disease. They will be used to publish a new book and set up an exhibition scheduled over the next two years. Once the research has been completed, we plan to publish a detailed report with information about the testimonies, summaries of the interviews, a profile of the interviewees, technical information and extracts from the statements. Let us now move on another part of the history of Hansen's disease, through transcriptions of longer passages from the interviews.

\section{Key figures in the creation of Morhan}

Initially named Movement for the Reintegration of Hansen's Disease Patients, Morhan was created on June 6, 1981, during the golden age of Brazilian social movements. It first emerged as an organization for the physically handicapped in general, although a specific group for those disabled by Hansen's disease was set up soon afterwards. Support was mobilized mainly among former patients, or those still living in leper colony hospitals when the official recommendation came to close down these asylums and introduce measures into the national health service to control the disease. Little by little, the movement gained the backing of outpatients and authorities. Reinforcing its identity as a movement for the minority, it extended the focus of its struggle to the control of the endemic, claiming that it was not simply trying to combat the disease, but also secure the organized participation of patients, authorities and even the general population in favor of improving the quality of life for patients.

According to Amaral (1990), Morhan shattered the stigmatized image of a movement in search of charity by adopting an approach to defend the rights of citizens, under similar conditions as the other popular movements of the time. The participation of Morhan in Hansen's disease control policymaking was made official nationwide in 1986, influencing the make-up of state technical commissions and municipal health

\footnotetext{
${ }^{14}$ Reports have been written by former patients and doctors from hospitals in several regions of Brazil about their experiences with Hansen's disease. Using oral history, we intend to publish the experiences of those who have not registered their memories in any other form.
} 
councils. (Nogueira, et alii, 1989). Nowadays, Morhan is comprised of patients, former patients and representatives from several professions. For reasons that will be explained in due course by the witnesses, it has changed its name to Movement for the Reintegration of People Afflicted by Hansen's Disease.

The coordinator of Morhan (Francisco Augusto Bacurau ${ }^{15}$ and, more recently, Artur Custódio ${ }^{16}$ ) has had a seat on the board of the National Health Council since the council was set up and he represents other SUS users. The movement's regional centers today embrace practically all Brazil's states and most of the leading municipalities. Despite the development of Morhan as a social movement, it is important to emphasize the fact that few of its members actually suffer from Hansen's disease, while most are from former leper colony hospitals or sympathizers, not necessarily even working in the field of medicine. The recent membership of Brazilian singer Ney Matogrosso is an example of this, while his support is indisputable not only to strengthen Morhan, but also to step up political pressure to prioritize public campaigns on the disease in Brazil.

The two following statements deal with the creation of Morhan and the organization of one of the regional centers. The exclusion from this report of Bacurau, the founder of Morhan, is compensated by one of the witnesses who recalls his first days with the organization in the Lauro de Souza Lima Hospital in Bauru, São Paulo State. He is Thomas Frist, a North American social scientist who, at the end of the 1970s and the start of the 1980s, set up a project involving patients from the communities surrounding the old leper colony hospitals.

The second statement was given by Cristiano Torres, from Pará State, who spent time in prevention centers and leper colony hospitals

\footnotetext{
${ }^{15}$ Francisco Augusto Vieira Nunes, a.k.a. Bacurau, was born in Manicoré, Amazonas State, in 1939. He contracted Hansen's disease when he was six years old and could not attend school. He was interned at the Porto Velho Leper Colony in Rondônia State when he was 14 and later in colonies in Acre State. He spent 21 years in the colonies. Self-taught, he became a primary school teacher after he left the colony. He is the author of the books Margens da vida and Chico-Boi, and has written many songs. Whilst in Bauru, São Paulo State, for surgery that would allow him to stop using a wheelchair, he joined the movement for the rights of the disabled. He was one of the leaders of the Executive Commission of the National Coalition of Organizations of Disabled People, which is comprised of sixty institutions. Shortly afterwards, he founded Morhan. He was the first former patient to participate in the technical commission of the Brazilian Program for the Control of Hansen's Disease and helped create the International Association for Integration, Dignity and Economic Advancement (IDEA). Decorated with many awards, he died of cancer in 1997.

16 From Rio de Janeiro, health sector professional and member of the board of Morhan for nearly twenty years, Artur Custódio Moreira de Sousa replaced Bacurau as the national coordinator of the movement and has since been reelected in national meetings of its regional centers. Aside from leading the national representation of the movement, he has fought for the consolidation of the SUS national health system and for social protection for people afflicted with Hansen's disease.
} 
since his childhood and was a leading figure in the process to resocialize patients from the Marituba Colony in Belém, Pará. He is the regional coordinator in his state and has been a member of the Morhan board for many mandates.

The interviews that were edited for this publication were conducted at the XVI International Leprosy Congress, held in August 2002 in the Bahia state capital of Salvador, which was attended by a large number of users, researchers and authorities from the social area.

\section{The paths that led Tom to Hansen's disease and brought him to Brazil}

I was born in Tampa, Florida, on June 2, 1945. My father was a Presbyterian minister and my mother was a writer. I grew up in Alabama. My father died when I was 13 ... . I studied in Tennessee and then attended a small university called Davidson College, in North Carolina. I read social sciences and health and also spent a year studying in France, at the University of Montpellier. I later won several Fullbright scholarships and became a teacher in India.

I was in Vietnam in 1968 ... . It's what a lot of people call the second stage of the war, more radical on the part of the United States. I was against the war and managed to find a job with Unicef working with refugees. When we went home, I studied for two years at Yale. I had to study something so I chose Hansen's disease because I'd worked with patients in India and Vietnam. I contacted the American Leprosy Missions (ALM) and won a scholarship to go to Tanzania, where I spent six months studying the disease in patients. I lived in four former patients' settlements ${ }^{17}$ and also at the hospital. I wanted to know why these settlements existed and what could be done to do away with them and give the residents more dignity...

ALM liked my report and, when I returned, offered me a job in another endemic country. I married my present wife, Claire, who was born in Costa Rica and is a US citizen of British descent and has a great love for Latin America. ... I contacted Jorge Macedo, from Cerpha, ${ }^{18} \mathrm{a}$ Brazilian NGO linked to ALM, and we decided to come to Brazil to study the factors preventing the social integration of people with Hansen's disease. Before arriving, I spent three months in Venezuela observing disability prevention programs ...

\footnotetext{
17 Settlements of former patients from leper colonies or leproseries. They are generally located nearby these establishments.

18 Cerpha: Evangelical Commission for the Rehabilitation of Hansen's Disease Patients, an NGO based in Rio de Janeiro. It adopted the name Palavra\&Ação (Word\&Action) in the 1990s and no longer exists. It played a key part as a go between in the receipt of funds from foreign NGOs associated with ILEP (International Leprosy), an institution that comprises most of the organizations that work with Hansen's disease.
} 


\section{His arrival in Brazil and his work in Bauru, São Paulo}

I arrived in Rio de Janeiro in December 1973. They had suggested that I go to Citrolândia, Minas Gerais. But once I'd been there and other places, I chose the Aimorés Sanatorium in Bauru, which was in the middle becoming a specialist hospital for sanitary dermatology. ${ }^{19}$ The first thing I noticed was that it truly was an enormous project and we were all alone. This is why the support of people like the doctors [Diltor Vladimir Araújo Opromolla] e Oswaldo Cruz ${ }^{20}$ was so important. I insisted in setting up my office in the center of town, in the community, because I believed that the whole project should be based in the town instead of the hospital seeing as I was, after all, preaching integration. For two years I organized a study group for people from university, social services ..., forty people were involved. We prepared several surveys. One involved more than a thousand patients from the hospital of a settlement of former patients, Vila Santa Terezinha. We also studied the attitudes of employers, professionals from the general population, in seven small towns from the region. We interviewed more than a thousand patients and tried to understand what made them different from one another: those from the hospitals, those hidden away in the settlement and those from the community. Why did some return to the community and others not?

Once we had completed the studies, we prepared a project, a plan of action involving the hospital, the community, the socio-economic part and the medical part, the transformation of society. I gave it the English name Pro-Rehab. In Portuguese, we called it Project to Rehabilitate Hansen's Disease Patients in Bauru.

There were many goals. One was the transformation of the Aimorés Sanatorium, in order to help Dr. Opromolla to advance the Lauro de Souza Lima Reference Hospital. Back then, between six hundred and a thousand patients lived there. So we divided the sanatorium into two parts: the hospital and the social area. The latter, in turn, was again divided into an asylum for the people who

\footnotetext{
19 The Aimorés Sanatorium changed its name to the Lauro de Souza Lima Hospital. At the end of the 1990s, it became a part of the São Paulo State Health Department as science and technology institute under the name Sanitary Dermatology Research Institute. Nowadays it has the biggest library specializing in Hansen's disease in Latin America and is a reference for Bireme. It has maintained the same architectural structure of the old colonies, with a hospital area, a more modern building for research and teaching activities and an asylum for elderly former patients and the disabled. The latter part is being restored as historical heritage. Once restored, it will be transformed into a museum.

${ }^{20}$ Dr. Oswaldo Cruz was director at the time the Aimorés Sanatorium was restored and changed its name to the Lauro de Souza Lima Hospital, while Dr. Diltor Vladimir Araújo Opromolla is the current head of research at the Lauro de Souza Lima Institute; he joined the staff as a doctor in the 1960s, having been an admirer of Lauro de Souza Lima.
} 
would never leave and a part for those who would one day be able to leave. We would work with these people to help them return to their towns of origin. The idea was also to prevent new patients from being sent there. So a part of the project was just this, transformation. Our connection with the ALM and other international organizations helped us raise the funds to set up the rehabilitation teams. We planned to pay staff until the government hired them. A team was set up for physical rehabilitation, a library, stuff like that ... . Another part was to upgrade the settlement of former patients, Vila de Santa Terezinha, next to the hospital. The settlement was very closely linked to the hospital, people came and went all the time. The hospital supplied the water, electricity, postal service, everything ... . I helped set up a residents' association. We managed to register the properties and they soon began to rely less on the hospital: a well, telephone lines, buses into town that helped the residents get out and health officials get in .... These days, the settlement is very integrated. The project also included the introduction of programs to prevent disability in the main Health Center in the town of Bauru.

Another of my projects was the creation of the Society for the Rehabilitation and Reintegration of the Disabled (Sorri), because employers were not accepting people who were in any way disabled or those with Hansen's disease (...).

The new headquarters of Sorri was inaugurated in 1981. It was the first event of the International Year of Disabled Persons. Bacurau wrote the song "Let's Sorri [smile] for life". Sorri grew quickly and we now have nine Sorris around the country. There are these puppets, The Neighborhood Gang. You may know the character Ana Melo, who has Hansen's disease? They won several Unicef awards. ${ }^{21}$

\section{The creation of Morhan}

Well, the movement of disabled people that would give rise to MORHAN began in 1979. Four or five people started to meet in São Paulo in preparation for the International Year of Disabled Persons, in 1981. We wanted to take advantage of this opportunity make a difference. We made contact with the movement for the rights of disabled persons in São Paulo. It was for all disabled people. There were blind people, wheelchair-bound people... There was a fair amount of prejudice against those who were disabled by Hansen's disease. They simply weren't accepted. This was interesting, because

\footnotetext{
21 Sorri uses puppet shows in its campaigns against the stigma associated to physical and social disability. Hansen's disease is among the problems embraced by the organization. Ana Melo is a character used in teaching material and in Hansen's disease-related campaigns.
} 
we were fighting prejudice and the disabled were prejudiced themselves. But once they were cured, they were no longer considered patients, nor Hansen's disease sufferers or anything, they were just disabled...

So I thought: "Look, I'm an American, I'm not disabled, I haven't got Hansen's disease, so what I need is someone, a Brazilian, disabled and with Hansen's disease to lead the struggle. I'll lend him all my support, but he'll have to be the leader because it concerns his own plight."

Finally, in Bauru, an occupational therapist said: "Ah, there's a patient here from Acre for foot surgery. The name's Bacurau. Talk to him because he's only been here a little while and he's seems smart". So, I spoke to Bacurau, who was still bedridden, and he accepted. We started participating in meetings in São Paulo, once a month, for several months .... . Meanwhile, we were organizing a nationwide event in Brasilia for the disabled from all states. We took one group to Brasilia, a busload of sixty people, ten with Hansen's disease. There, a national coalition of disabled people was set up with other states, with Bacurau elected one of the five leaders of the movement. Bacurau started to travel around to visit other colonies ... . He was friends with people in Belém and he had the idea of creating an organization representing people with Hansen's disease only. At first I didn't approve: "No, what we need to do is to integrate the professionals and the people with the disease, anybody interested in the struggle, because the struggle unites us, but you don't want to create this. This is segregation..." - I said.

I wanted to integrate the already existing organizations for the disabled, but I soon realized that this wasn't going to work because they really wanted a separate movement. A meeting was held with other entities, people from Casa Andréa, in Belém, from Sorri in Bauru and organizations for the handicapped. The decision to set up Morhan was made at this first meeting and I helped Bacurau write the statute that was approved. [Diltor V. Araújo] Opromolla was the only member of the medical profession present at the meeting.

Bacurau wanted the headquarters to be the hospital or in the neighboring settlement. But I said: "No, that's not right. You have to be where the power is, in São Paulo." We found a place in São Bernardo do Campo (just outside São Paulo). We helped a lot in the first two years. The movement began to grow, although some members were extremely radical and started to attack the medical staff, the management $\ldots$, at times for good reason, other times not.

\section{Changing the name in Brazil to reduce the stigma associated with the disease}

The same thing occurred in the United States. I think it's positive, although not all that important. As far as I'm concerned, to remove 
the stigma, instead of changing the name, it is far, far more important to change the social fabric and promote integration and inclusion, to restore people's dignity. I thought we spent far too much time discussing the name in the 1980s and 1970s, instead of addressing more important issues. When I write, I always refer to both names. You can't properly write about the past using the term 'hanseniasis'.

One thing I've never liked is the term 'hansenian' [one with hanseniasis'] and I argued bitterly with Bacurau over this. It was Dr. [Abrahão] Rotberg who came up with the term and I used it in the project to rehabilitate patients with the disease. Morhan was a movement to integrate 'hansenians'. After I'd thought about it for a while, I changed my mind. But the word is problematic because it identifies a person by the disease, even when he is no longer sick. Even in the last book I wrote, The descendant, there is a lot about the struggle of a patient, a former patient. We still even use the word patient.

I spent 14 years in Brazil. Eleven years in Bauru and three in São Paulo, setting up Sorri-Brasil. Afterwards, I was invited to become president of the American Leprosy Missions ... . I returned to the United States and became president of the International Federation of Anti-Leprosy Associations (ILEP). But I often used to meet up with Bacurau. We saw each other in China lat the XV International Leprosy Congress] and we've met up in other places. Morhan grew a lot and we were still friends. I called him in Acre for a chat three or four days before he died. I'll always visit Brazil. I love this country.

\section{Cristiano Torres: memories of his parents and siblings.}

I was born in 1939 in the Prata Colony, 110km from Belém do Pará, in a municipality called Igarapé-Açu. ... I'm the son of two patients. My mother and father met when they were young, fell in love and married. They had 13 children that were planned, two that weren't. Only three are alive today. I've many nieces and nephews, including a niece who is married and lives in Rio de Janeiro. We were all born in the leper colony. Back then, the doctors and directors of the hospital told my mother, after she gave birth to her first child, that she shouldn't have any more children. But she said no, that she needed to have children to feel like a woman, to feel fulfilled. I was the second. Then she had the others. ${ }^{22}$

\footnotetext{
${ }^{22}$ It is known that strict rules were enforced to try and prevent procreation in leper colonies in Southern Brazil. In some cases, a sterilization policy was introduced, although seemingly little effect.
} 
First days in the prevention center ${ }^{23}$; symptoms of Hansen's disease and meeting his parents

I was one of those poor children who lived in nurseries. They were called nurseries. There was one in Pará, the Santa Terezinha Nursery, in the center of town. Because there were so many of us in the colonies, more people were getting married and more children were being born. I went from one nursery to another covered with the marks of Hansen's disease. This was in March 1994. I would soon be six years old.

I went to a colony in Marituba, which is a long way, about $100 \mathrm{~km}$, from where my parents were. Marituba, where I live today, is a metropolitan area. A nurse who knew my mother from the Prata Colony said: "What is this child doing here? He's already got Hansen's disease, so why doesn't he go an live with his mother and father?" This was how I came to meet my parents, seeing as they couldn't visit me because in those days you weren't allowed to leave the colony. ...

It was so painful and such a shock! Since then, once I'd grown up, I realized that it wasn't so painful after all, nor such a shock. But back then it was. My mother had severe deformities, because there was no antibiotic available at the time to treat the disease, only chaulmoogra oil, ${ }^{24}$ and there was no way of preventing disablement. But I was lucky to have an intellectual mother. I'd tell her sometimes "You fancy yourself as an intellectual." "No, my son, I'm not an intellectual, but I've studied, and learned." She went to a good college in Belém, one of the best, because my grandfather was wealthy. He sent her to this college ... where she did the normal course and also learnt the piano. She was a cultured woman, she had a certain aptitude for these things. She contracted Hansen's disease in her final year. She was so, so young - 19 years old - she went to the colony, where she met my father. They fell in love, married and had children. So I went to live with them. My memories those times are terrible, I don't like to think about it too much...

I'd been living with children who were supposedly normal, without skin lesions, good-looking... When I arrived, they told me:

\footnotetext{
23 Prevention centers were generally located nearby the leproseries and housed the children born in the leproseries who were quickly separated from their parents. This method of controlling Hansen's disease in Brazil began to be implemented in the 1920 s, at the same time as the construction of leper colonies spread for the compulsory isolation of patients. However, sometimes the prevention centers were located far from the hospitals, even in different towns.

${ }^{24}$ Reasonably effective, chaulmoogra oil is a phytotherapeutic medicine that was applied as an oil (bathing and wet dressing the wounds) or by injection in the treatment of Hansen's disease from the $19^{\text {th }}$ century right through to the 1940s. For more information, see the Sources section of this issue.
} 
"this is your mother and this is your father" ... . They were covered with lesions. It had a horrible impact on me. I cried so much! Three days later, I asked the people there if I could swap mothers, because I wanted a prettier mother. This must have been devastating for my mother... But I was just a kid and I wasn't used to this kind of environment. Later she acknowledged this, as did I... I never stopped apologizing for the way I'd behaved. After a while I got used to the place, but the initial impact was terrible. I saw people at the colony with terrible lesions. There was no way to prevent the disablement caused by leprosy reactions. ${ }^{25}$ Some of them really did have lionfaces! ${ }^{26}$ It was awful for me. I didn't have... . anything visible, just a small mark. I stayed at the Prata Colony ${ }^{27}$ with my parents until I was nine years old, when one of the directors, Alfredo Brumpt, a German, asked to speak to us and said "Get this child out of here. He's only very slightly affected by Hansen's bacillus, he'll be contaminated, he'll get worse." I had to test negative on 12 consecutive examinations and, once this was done, I left. ${ }^{28}$

So really, I'd never had a grandfather, or a sister, or even an aunt. I'd never felt the warmth from a family of your own flesh and blood that other people feel. My father's background was similar: he was abandoned by his family, and he was young when the symptoms first appeared. He went to the Prata Colony, where he spent his whole life. He used to play soccer, he liked the sport, those kind of things. We could all learn something from this situation.

\section{Leaving the Prata Colony and starting work}

I went to live in Belém, [on Rua da Estrela, currently Rua Mariz e Barros, in 1949 or 1950]..$^{29}$ My father's cousin bought a house and gave it to my father, gave him some money too, and he set up a small

\footnotetext{
25 The physical disability or deformities resulting from Hansen's disease may be avoided with the use of specific medicines during severe reactions and also with physiotherapy and preventative techniques to protect against losing nerve sensations in hands and feet and around the eyes. Unfortunately, the priority given to chemotherapy delayed the introduction of this treatment, which is still little used in endemic countries.

26 Leontiasis, or 'lion face', is a hardened, lion-like appearance of the face that occurs in the advanced stages of Hansen's disease. ${ }^{27}$ Founded in 1924, the Prata Colony was the first agricultural colony for Hansen's disease patients in Brazil. This type of institution was also used for patients with psychiatric problems, such as in the Juliano Moreira Colony, set up in Rio de Janeiro in 1922.

${ }^{28}$ Since the introduction of chemotherapy with sulfone, before being discharged patients had to take a biopsy, in which skin secretions were taken from certain parts of the body, to check for the presence of the bacillus (Microbacterium leprae). They were only discharged when they consistently tested negative, hence the reference to 12 tests.

${ }^{29}$ Here, the witness is referring to his first years living outside the leprosery. Nearly ten years later, he had to return to the leprosery after he failed to take the full course of medications and the disease recurred.
} 
store in the living room so we could make a living. He sold coal, eggs, vegetables... So I had to work too. Just me, my mother and my father. My other brothers and sisters lived in the nursery because they didn't have Hansen's disease.

When I came to live in Belém, when I was nine or ten, ... I said: "Father, I'm going to work, but I won't live without my brothers and sisters. I want them close by." One was already seven, another, five. They were all small, and only four of the many that were born were still alive. I didn't want to be denied my playmates. Seeing as they are my brothers and sisters, why should we be separated? But dad said, "Son, look around you, I just don't have the financial means to support these children, how will we manage?" "Father, I don't care about our financial situation, let's just share what we do have. It's poverty, but let's at least share our poverty." So I got a job and worked hard. ${ }^{30}$ I started working as an office boy and a laborer, while my father worked at home. My brothers and sisters also started to help, because aside from the lesions he had, he was also nearly blind. Giving people their change became difficult for him. My mother had her housework, but she had lesions on her hands. So my brothers and sisters and I would help out, ... . We learned to do the accounts. The old man did the calculations in his head because he couldn't write. So he'd say: "The change is so much, how much did I give you?" They sold coal and eggs, anything at all, and dad would say: "How much did he give? This much? So the change is so much." He did it all in his head... And that's how we lived our lives.

\section{First problems with Hansen's disease and his return to the Marituba Colony}

As time went by, I started to suffer from Hansen's disease: pains in my joints, fever and nodules that are symptomatic of the illness and it got worse, despite the treatment. Dr. Alfredo Brumpt recommended that I continue treatment with dapsone, sulfone. And, like the child I was, didn't want to. You know, it didn't hurt, so I didn't really think much about what I ought to be doing. Dad said: "Listen, you need to go to the dispensary." ${ }^{1}$ But I didn't go. I didn't worry about it. Soon I started to have, well, I'm not sure if it was a relapse or if I was contaminated again. But I definitely had no resistance and I was contaminated, I started to experience problems, and I was the one who

\footnotetext{
30 Later, once the interview was over, the witness explained that he had done odd jobs, as an assistant in supermarkets and even as a shoeshine boy.

31 The dispensaries were part of the public health network for the treatment of Hansen's disease and tuberculosis. Later, they were transformed in Health Centers for general outpatient treatment.
} 
was supporting the family. I kept at it, kept on trying, but when I was 21 there was no way I could continue treatment at the dispensary. I had to return to the leprosery, this time to Marituba. My father was becoming increasingly more incapacitated, he was already blind, my mother too, and by this point my sister was married and my other sister went to live with her. My parents and I had to return to Marituba and the family was split up again. My father wanted to go back to Marituba, my mother did too. But I didn't want them to return to Marituba, not me. I had to go too and I went with them. ... . And when I got to Marituba, I had to re-experience everything I'd encountered as a child. I arrived, very tearful, on April 21, 1960, the day of the inauguration of Brasilia. I was raining that day and my eyes, you know that uncontrollable weeping, the tears were streaming down my face. My mother, when she realized, called me over. She was very understanding: "Why are you crying?," Not now, mum, right now I'm not emotionally capable of saying, but I'll tell you later." A few days later, I said to my mother and father, "look around you, colonies are depositories for the sick, depositories for lepers. I didn't come here to die. Just you wait and see, I'm going to fight for my life! I don't know what I'll do, but I'm going to break some of the taboos around here, I'm going to be a rebel."

\section{Marriage and housing in the colony}

To begin with, for a while after I was married, I didn't have a house, because they were all occupied by other couples. So I lived with my parents. Actually, just my mother, because my father had already died... But I wanted my own house. ...

In 1964, the impact of the military coup was also felt in the leper colonies. We knew what was going on in the outside world... He arrived on August 13, 1964. The state governor appointed by the revolution visited the colony. We'd heard that he was coming five days previously. Both my parents were living in the communal part of the colony. Houses became available, but they weren't offered to my parents because of my rebelliousness. It was a form of punishment. They realized this would upset me because my parents weren't to blame for what I was doing .... So I told them I'd get a house by asking the governor. And, Lo and behold!, two days beforehand, they called me in and said: "Here it is, a lovely reformed house, nicely painted". They gave the house to my father and I went to live with my mother in 1967. After I was married, I considered moving into my own house, but my mother would have been all on her own if I'd left, and that wouldn't have been fair. I thought it would be extremely unfair. We had already suffered so much together, why split up now? I ended up staying with my mother, with my wife, more or less seven years. We were separated later on... 


\section{About work and leisure in the colonies: means of survival}

The doctors quickly assessed our level of intelligence once we arrived in the colony. Although I was already presenting Hansen's disease reactions, my hands were still in perfect condition and they still hadn't lost their nerve sensation. The first thing they taught us was to apply the cupping glasses, a treatment I don't think is even used any more. They also taught us to administer intramuscular injections, check blood pressure, temperature, handle the thermometer, and afterwards we learnt to apply bandages. I did a quick training course, because at this point the so-called medical staff, who worked in the health sector, would not touch the patients to apply bandages. You had to be sick to do this, so we were trained and we did it! What was worse is that the minimum wage at the time was thirty three thousand cruzeiros per month. We were exploited, but we had to do it, otherwise we'd have died of boredom ...

So life was fantastic until I was nine years old, when I was in the Prata Colony. Let me backtrack a little... My mother and some of her friends were intellectuals, because they studied. She wrote, compose poems, she knew how to play the piano. Other people who'd gone to university, studied law, others, I don't know, from several professions. These people, who all suffered from Hansen's disease, got together to form a group. They were also rebellious and started to print a newspaper. They got hold of a mimeograph, ran off the newspaper in our house and I distributed it during the night. It was harder for the local policeman to catch me in the dark — me, a child — than to catch an adult, so I ran around pushing this newspaper under people's doors. It was called Clarim [Clarion], like a shout of protest. It was a criticism of the prophylactic measures, of the disciplinary measures in the colony, harsh criticism. Criticism of the medicine, because of the drugs. It also contained some praises, it was a newspaper with ideas, culture too, but the main theme was this. The editorial was always critical.

It was a small newspaper, because nobody had enough money to pay for it and the patients had to smuggle the paper in. ... This was the newspaper that was printed in my house. After a while, my father said: "Listen, they'll suspect us", because of its content, because of the way it was written, it would draw attention to the intellectuals. I remember clearly him discussing this with my mother.

Back then, there were some 550 or 560 people in the colony. Lots of people. To give you an idea, we had four soccer teams. So, they started to think about where they should hide the mimeograph they used to print the newspaper. I remember me saying, me, a little kid: "I know a place you can hide it," "Where boy?," "You could ask the nun to hide it in the church, because the police don't suspect nuns" ... . 
That newspaper that was printed in Marituba had a social column about the people who were celebrating their birthdays, it had new stories, such as the use of sulfone drugs to treat leprosy. There was also a theatre group in Marituba. I was part of it. Some of the group's members knew how to play wind instruments, others could play the guitar. Together, they formed a band. We didn't have sound systems like the ones we have today, that play CDs that you can buy anywhere. No, the music was live! We used to dance in the colonies. Those of us in the theater group came up with an idea: "Listen, it looks as if the governor is coming in August. Lets perform a play." Only it challenged the dictatorship! I played the part of an officer. We were so daring! The governor was Jarbas Passarinho, who had been a longstanding senator. I mean, we often did these kinds of things in the colonies: theater, folklore, São João celebrations, carnival, and we had samba schools with amusing names. The colony's two samba schools were called Casadinho and Traz aqui [Hitched and Come on down]. The former was for the married couples and Traz aqui for the singles. They were extremely competitive. We had the parades and the dancing, but as soon as the two carnival blocks met, the battle commenced, there were fights to try and break the other school's banner, their drum sticks, to smash snare drums over people's heads, until blood started flowing. Then we'd head to the hospital for bandages and the police would intervene. Recalling my vow to my parents, that I wasn't going to die of boredom, that I'd gone there to fight, I tell people the following: Hansen's disease threw me into the world inside a furnace, and life is an anvil and a hammer that has forged my personality and my citizenship. I have no doubt about this.

\section{Back to studying and role in the political and social arena}

I kept writing to him [Jarbas Passarinho], saying that my life's wish was to complete my high school education. He authorized a scholarship and I went to Belém to look at schools. ... I turned up, asked if they had places and was told that they did. "Wait here, I'll just fetch the paperwork." So he took my details. "Residence?" I told him "Marituba Colony." The guy scratched his head and said: "Wait here a moment, I'm a bit thirsty, I'll just get a glass of water," and in he went, only to return with one of the headmasters: "Listen, there's been mistake young man, we don't have any places." Marituba Colony was a synonym of leprosy. I went back home with my scholarship under my arm. I had a friend there who was the daughter of a patient, she wanted to study and she didn't have Hansen's disease. I gave the scholarship to her: "Here you are, go and study." She's a teacher today, she studied pedagogy. But I got to thinking and proposed to some colleagues: 
"You know something? Let's do a High School course on our own?," "But how? Who's going to pay?," "I don't know, man, let's just do it."

We started with thirty students. We found some volunteers studying at the local university who taught some mathematics, chemistry, science. But I was involved in the social movement again, and it took up lots of my time. ... I managed to pass some subjects, math, chemistry. Funnily enough, I didn't pass Portuguese or History. It's about ten years ago now and I quit because I was too busy with the social movement. But it's still a dream I have. I've told the people at Morhan: I'm a fellow who likes to do what I think, I've got two more years with the social movement, so I'll go to university when I'm 55 or 56 and I want to receive my diploma when I'm sixty, because I want to show an example. And the guys who know me said: "There's no doubt about that. You'll do it."

\section{Initial contact with Morhan}

Morhan was founded by eight people in São Paulo, although they were all northerners. Four were from Pará and lived in Marituba. Actually, three lived in Marituba; one lived in Belém, but was interned in Marituba. He was Curica ... They were the ones who came up with the idea: "Cristiano, come here," "What's up?" "Listen, man, a movement has been set up in São Paulo called Movement for the Reintegration of Hansen's Disease Patients. Don't you want to get involved?" ... So we went to the first Morhan meeting. At the second meeting, in São Bernardo, I said: "I'm not going to let these guys off lightly. I'm going to tell them what I really think, ... but only if you all help me with the change." "What change?" "Change this Movement for the Reintegration of Hansen's Disease Patients charade. I'm not a 'hanseniano', even though it rhymes with Cristiano, nor am I an 'ex'. Let's change this. The acronym has stuck, we can keep Morhan, but it should be Movement for the Reintegration of People Afflicted with Hansen's Disease. It sounds different." Otherwise health sector staff would continue use the terms 'hansenian' or 'ex-hansenian'. I've even asked this. ... why do you still use the pathological term refer to us? You've stopped calling us lepers, but you now you call us 'hansenian'. You've changed the name, but you still use the pathological term. You don't call people ex-flu patients, "Hey you, ex-flu patient, come here!" but you do say 'ex-hansenian'. I mean, the stigma is still attached, the prejudice. As far as I'm concerned, this is terrible!

When I said this at the Morhan meeting, all hell broke loose. The conservatives retorted: "What? This guy comes here and tells us what to do?" But Bacurau stood up and said: "Listen, what Cristiano said is very pertinent and I think he is right, because we are fighting for our citizenship but allowing people to keep calling us by a different 
name. They are stripping us of our identity." From then on, the movement became known as Movement for the Reintegration of People Afflicted by Hansen's Disease. After that, I wore the T-shirt and I've fought hard for the cause. ...

I'm part of the movement, there's no denying it, how else am I going to pressure the government to take more action? If it were Lula [nickname of former opposition leader and now Brazil's President Luiz Inácio Lula da Silval, we'd pressure him too, you can be sure of that. I know the difference between party politics and other things, I know it well. I want improvements made to the health system in general. I had to read up on the [National Health System] SUS before I could draw my own conclusions. During the health movement to create the SUS, I was there. I was in Brasilia, with the social movement. For me, that was a great privilege. We helped shape this thing.

I tell people that I don't know any better national health system in this country than the SUS. It's so good that the authorities don't want it to be implemented. Brazil will eliminate Hansen's disease by 2005, ${ }^{32}$ but not Pará. The prevalence of the disease in Brazil is four in every ten thousand inhabitants, while in Pará it is forty. I say Pará will not eliminate Hansen's disease, or even control it, not even by 2010.

But they wont let us implement this new SUS system we want, even though it looks so good on paper. I've had arguments with the health secretary from my municipality, who sometimes conveys what I say to the mayor, who replies: "No, let's go and see, let's talk to Cristiano, his position is correct, we'll ask him, what is it Cristiano?" "Well, Mr. Mayor, it's this, that and the other," and the mayor listens. "I represent, Mr. Mayor, a community that wants something from us." ... sometimes I say to him: "You know something, Mr. Mayor, the decision is political, it's yours, but the Health Council is leaning this way." Proof of our influence is that one of us was president of the Health Council when the new mayor was elected, just over a year ago. In the first council meeting, we managed to get the Municipal Legislative Assembly to agree not to make the Health Secretary the president of the council. We achieved this through pressure from the social movement.

I would do it all again, just a little better and with more determination, if I had the opportunity .... Sometimes I tell my colleagues that we hitchhiked to the first Morhan meetings and when we got as far as Imperatriz, Maranhão State, the guy would say: "This is as far as I go". So we'd hop out and thumb another lift. These days, we go by

\footnotetext{
32 The goal to eliminate Hansen's disease in Brazil is actually to lower the prevalence of the disease to less than one case in ten thousand, in line with World Health Organization recommendations. This means reducing the levels of endemicity and the risk of transmission, which is not the same as elimination, which suggests total inexistence of the disease.
} 
bus and the hotel is paid for, although I don't know who by ..., but somebody believes in us. At times we were pioneering, we realize that, we want to be a shining example. But at other times, people may have thought we made mistakes. This is bound to happen, there's no doubt about it, but it has been extremely gratifying, despite all the difficulties. At the end of the day, it was worth it.

\section{Fact Sheet}

Interviewees: Thomas Ferran Frist, Cristiano Cláudio Torres, Fuad Abílio Abdala e Abrahão Rotberg

Interviewer: Laurinda Rosa Maciel e Maria Leide Wand-del-Rey de Oliveira

Transcription: Maria Lúcia dos Santos and Mariana Damasco

Accuracy check: Nathacha Regazzini Bianchi Reis

Date: 08.09 .2002

Location: Salvador, Bahia

Translation to English: Words and Words

Portuguese editing: Natércia Rossi and Jaime L. Benchimol

\section{BIBLIOGRAPHIC REFERENCES}

Alberti, Verena 1989

Amaral, Ruth dos Reis 1990

Bomeny, Helena (org.) 2001

Bosi, Ecléa 1995

Brasil/Departamento de Imprensa Nacional

Brasil/Departamento de Imprensa Nacional. 6.11.1996

Burke, Peter (org.) 1992

Claro, Lenita

Barreto Lorena 1995

Conasems 1999

Del Fávero, Wandick 1971
História oral: a experiência do CPDOC. Rio de Janeiro. Editora da FGV.

A participação do Movimento de Reintegração do Hanseniano (Morban) no controle da hanseníase no Brasil. Monografia de conclusão de curso de sanitarista, Rio de Janeiro, Escola Nacional de Saúde Pública.

Constelação Capanema: intelectuais e políticas.

Rio de Janeiro, FGV.

Memória e sociedade: lembranças de velhos.

São Paulo, Companhia das Letras.

Diário Oficial da União. Portaria no 95 , de 26 de janeiro de 2001 (NOAS/SUS, 01/2001)

Diário Oficial da União. Norma Operacional Básica do Sistema Único de Saúde/ SUS (NOB 01/96).

A escrita da história: novas perspectivas. São Paulo, Unesp.

Hanseniase: representações sobre a doença. Rio de Janeiro, Editora Fiocruz.

Como os gestores vão acelerar a eliminação da hanseniase no Brasil. Brasília, Conselho Nacional de Secretários Municipais de Saúde/Conasems. 28p.

'Integração das tarefas de controle da lepra nas unidades sanitárias não especializadas'. Boletim da Divisão Nacional de Lepra, vol. XXX, nos 1 e 2 . 
Dyer, Isadore

Ferreira, Marieta de Moraes; Fernandes, Tânia and Alberti, Verena (orgs.) 2000

Ferreira, Marieta de Moraes and Amado, Janaína (orgs.) 1996

Ferreira, Marieta de Moraes (org.). 1994

Frist, Thomas Ferran 2001

Frist, Thomas Ferran 1996

Gomes, Ângela de Castro (org.). 2000

Hochman, Gilberto 2001

Hochman, Gilberto e Fonseca, Cristina 2000

Mancuso, Maria Inês Rauter jan.-jun. 1996

Ministério da Saúde/ Secretaria de Políticas de Saúde/Área Técnica de Dermatologia Sanitária 2000

Mohran

Nogueira, W. Amaral, R. R.; Oliveira, M. L. W del R.; Pereira, G. F. M. and Barroso, $M$.

Oliveira, Maria Leide Wan-del-Rey de 1990

Rabello, Ernani apud Diniz, Orestes maio 1948
'The origin in Louisiana leprosy'.

Apud, Souza Araújo.

História oral: desafios para o século XXI.

Rio de Janeiro, FGV.

Usos E abusos da história oral.

Rio de Janeiro, FGV.

Entrevistas: abordagens e usos da bistória oral.

Rio de Janeiro, FGV.

The descendant. se,

North Caroline

Don't treat me like I have leprosy.

London, TALMilep.

Capanema: o ministro e seu ministério.

Rio de Janeiro, FGV.

'A saúde pública em tempos de Capanema: inovações e continuidades'. In Helena Bomeny (org.), Constelação Capanema: intelectuais e políticas. Rio de Janeiro, FGV, pp. 127-51.

'A I Conferência Nacional de Saúde: reformas, políticas e saúde pública em debate no Estado Novo'. In Angela de Castro Gomes (org.), Capanema: o ministro e seu ministério. Rio de Janeiro, FGV/Universidade São Francisco, pp. 173-93.

O estigma da lepra: a experiência da exclusão.

Teoria \& Pesquisa, pp. 16-17, 34-44.

Projeto de eliminação da hanseníase no Brasil.

Brasília.

'Conferência de abertura do VIII Congresso Brasileiro de Hansenologia 29 de agosto de 1994, com Abrahão Rotberg'. Jornal do Morhan, nº 21, $3^{\circ}$ trimestre de 1985 , pp. 4-5.

'The role of patients/technicians association for Hansen's disease Control'. International Journal of Leprosy, 57, 1:361 (Suppl).

Articulação docente-assistencial: o caso do programa de controle da hanseníase no Rio de Janeiro. Dissertação de mestrado em dermatologia, Niterói, Faculdade de Medicina, Universidade Federal Fluminense.

'Profilaxia da Lepra: evolução e aplicação no Brasil'. Boletim do Serviço de Lepra, nำ 7. 
INTERVIEWS

Rotberg, Abrahão 'The Brazilian phase III of prevention of hanseniasis'

1980

Hanseniasis Internacionalis. São Paulo, vol. 5, nº 1, pp. 37-42.

Rotberg, Abrahão 'A lepra - moléstia psico-social'.

1970

Boletim do Serviço Nacional da Lepra', (2), Rio de Janeiro.

Rotberg, Abrahão

'Some aspects of immunity in leprosy and their importance in epidemiology, pathogenesis and classification of forms of the disease. Based on 1529 lepromin-tested cases'. Revista Brasileira de Leprologia, (5) 45.

Souza Araújo, Heraclides

César de

História da lepra no Brasil - periodo republicano. Volume III (1890-1952)

1956

Souza Araújo, Heraclides

César de

1929

Torres, Diana Obregón 2002 Rio de Janeiro, Imprensa Nacional, vol. III

A lepra: estudos realizados em 40 paizes (1924-1927).

Rio de Janeiro, Instituto Oswaldo Cruz.

Batallas contra la lepra: Estado, medicina y ciencia em Colombia. Medellín,

Tronca, Italo Banco de la Republica, Fondo Editorial Universidad EAFIT,

2000

As máscaras do medo-LeprAids.

Campinas, Editora da Unicamp.

Valverde, Belmiro

1915

Prophylaxia da lepra.

Rio de Janeiro, São Carlos. 